\title{
STUPENDEMYS SOUZAI SP. NOV. (PLEURODIRA, PODOCNEMIDIDAE) FROM THE MIOCENE-PLIOCENE OF THE SOLIMÕES FORMATION, BRAZIL
}

\author{
JEAN BOCQUENTIN \& JANIRA MELO \\ Laboratório de Paleontologia, UFAC, Campus Universitário, km 4, BR364, 69915-900, Rio Branco, AC, Brazil. \\ bocvillanueva@hotmail.com
}

\begin{abstract}
A new species of turtle, Stupendemys souzai, is based on one incomplete humerus and additional material from several outcrops of the Solimões Formation in the state of Acre. Diagnostic features of the species include the humerus noticeably less massive than in Stupendemys geographicus, the thick curved margin of the nuchal and peripheral 1 plates, the femoroanal sulcus located very anteriorly on the xiphiplastral plate, the posterior lobe of the plastron short and broad and the centrum of cervical vertebrae relatively narrow and excavated laterally.
\end{abstract}

Key words: Stupendemys, turtle, Neogene, Solimões Formation, Acre, Brazil.

\begin{abstract}
RESUMO - A nova espécie de tartaruga, Stupendemys souzai, da Formação Solimões (Mioceno-Plioceno) está baseada num úmero incompleto e em material adicional proveniente de diversos sítios no Acre. Os caracteres distintivos da espécie constam de um úmero menos maciço em relação ao de Stupendemys geographicus, de uma espessa margem recurvada na frente das placas nucal e periferais 1, de um lobo posterior do plastrão curto e largo, de um sulco femoroanal disposto anteriormente no xifiplastrão e de vértebras cervicais com centro vertebral estreito.
\end{abstract}

Palavras-chave: Stupendemys, tartaruga, Neógeno, Formação Solimões, Acre, Brasil.

\section{INTRODUCTION}

The presence of the giant turtle Stupendemys in the area of the northwestern region of Brasil was first recognised by the staff of the paleontological laboratory of the Universidade Federal do Acre, in State of Acre, Brazil (Figura 1). Fieldwork in the Mio-Pliocene beds of the Solimões Formation, mainly along the Purus and Acre rivers has yielded various fragmentary bone plates of this turtle, which was previously known only from the late Miocene of the Urumaco Formation of Venezuela with the extremely large species $S$. geographicus. Bocquentin \& Negri (1993) mencioned two vertebrae with saddle-shapped articulations and Broin et al. (1993) presented a detailed description of a thick humerus, a long pleural plate, a big xiphiplastron and vertebrae from the Patos and Cavalcante localities along the Acre River. In Bocquentin \& Guilherme (1997) described an almost complete pelvic girdle from the Cachoeira do Bandeira and Negri \& Bocquentin (1998) reported a cervical vertebra from Pedra Preta locality along the rio Juruá. Gaffney et al. (1998) published a nuchal bone from Cavalcante locality (=Acre 1) as Stupendemys sp.

The occurrence of Stupendemys would be of considerable paleogeographic interest, since the paleoenvironments of the Urumaco Formation are interpreted as inner sublittoral and costal lagoon with riverine and estuarine influence (Diaz de Gamero, 1989). Broin et al. (1993) assigned the Patos material tentatively to Stupendemys based on the thick structure of the fragments, but they emphasized the provisional nature of this identification because none of the fragments contain the diagnostically important "collar shell".

During several fieldtrips to the Solimões Formation, the discovery of additional specimens formed the basis of this study and justified the erection of a new Stupendemys species. Stupendemys souzai sp. nov. is characterized by a humerus (UFAC 1764) with more slender and longer shaft than that in S. geographicus. This paper redescribes the humerus UFAC 1764 from the Patos locality and describes recently discovered materials from two new localities of the Acre State: a nuchal bone, an hypoplastron and a new cervical vertebra. S. souzai sp. nov. is based on the humerus.

\section{COLLECTING SITES}

Patos and Cavalcante. These localities (LACM locality 4611=Acre 6 and LACM Locality $4418=$ Acre 1 of Frailey, 1986) on the rio Acre, have yielded the largest number of specimens. The diverse freshwater fish fauna including the Teleostei Acregoliath rancii, the Pimelodidae 


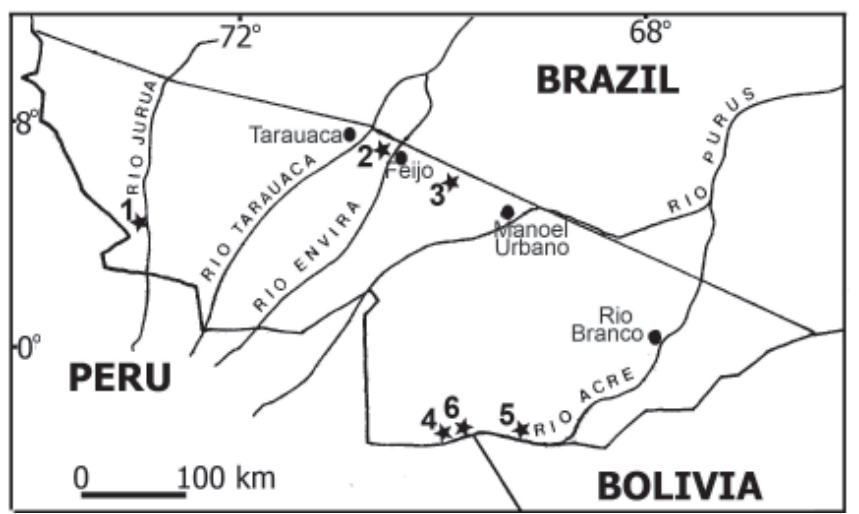

Figure 1. Map of the State of Acre showing the collecting localities (stars): 1, Pedra Preta; 2, Morro do Careca; 3, BR-364; 4, Patos; 5, Bandeira; 6, Cavalcante.

(Phractocephalus), the Characidae (Colossoma), the Dipnoi Lepidosiren, the sharks and rays reflect a lowland fluvial assemblage. Long-snouted, presumably piscivore, crocodiles are represented by the gavial Gryposuchus, the crocodilid Charactosuchus fisheri and the broad flat-snouted Mourasuchus. Among the caimans, Purussaurus brasiliensis had a estimated body size between 11 and $13 \mathrm{~m}$. Three different families of turtles are found here: the strictly aquatic Chelidae (Chelus colombiana) and Podocnemididae (Stupendemys souzai sp. nov.); and the terrestrial Testudinidae (Chelonoidis). At the Cavalcante site, Gaffney et al. (1998) reported the presence of a pelomedusoid with a shell "as large as or larger than that of Stupendemys". The mammalian fauna includes xenarthran sloths (Acremylodon campbelli), rodent caviomorphs (Phoberomys burmeisteri, Telicomys amazonensis, Potamarchus murinus, Tetrastylus and Kiyutherium), ungulate toxodontids (Gyrinodon, Trigodon) and protherotheriids, and Chiroptera (Noctilio lacrimaelunaris) was described. Fossil birds are represented by the Pelecaniformes Anhinga fraileyi.

The fossils from Patos and Cavalcante localities occur in clasts within the Acre conglomerate but the preservation of very delicate and yet complete specimens suggest little or no transport at all. This fauna is considered to be late Miocene (Huayquerian Land Mammal Age; Gaffney et al., 1998; Campbell et al., 2001). The fish fauna presents wide dietary diversity, including the frugivorous/carnivorous Colossoma macropomum that suggests the presence of fruiting plants along the river margins or in the flood plain. According to Campbell (1996), the composition of the fossil vertebrate fauna recorded at Patos site indicates an aquatic environment (Frailey, 1986; Baya \& Bocquentin, 1997; Campbell, 1996; Czaplewski, 1996; Bergqvist et al.1998; Negri \& Bocquentin, 1998).

Morro do Careca. This new fossiliferous locality of the Solimões Formation is situated along both sides of a road embankment, $15 \mathrm{~km}$ from the city of Feijo $\left(08^{\circ} 10^{\prime} 30^{\prime \prime} \mathrm{S}\right.$, $69^{\circ} 31^{\prime} 24^{\prime \prime} \mathrm{W}$ ). The fossils are found throughout the somewhat consolidated sedimentary rocks, consisting of isolated teeth and ends of bones and generally worn and broken. The fauna is represented by Osteichthyes fish, including Callichthyidae,
Characidae, Erythrinidae and Dipnoi; Crocodyliformes, with Purussaurus brasiliensis, Mourasuchus, Charactosuchus and gavials; turtles, Chelidae Chelus and the Podocnemidinae Stupendemys souzai sp. nov.; and mammals, represented by remains of xenarthran sloths and teeth of the rodent Neoepiblemidae Neoepiblema.

BR 364. This locality, is situated at approximately $15 \mathrm{~km}$ east of the city of Manoel Urbano $\left(08^{\circ} 30^{\prime} 54^{\prime \prime} \mathrm{S}, 70^{\circ} 02^{\prime} 21^{\prime \prime} \mathrm{W}\right)$. Most part of the identified fossil materials are referred to Purussaurus brasiliensis. Although the relative small size of this outcrop, it covers no more than $20 \mathrm{~m}$, the occurrence of Stupendemys souzai sp.nov. makes it an important site.

Pedra Preta. This outcrop is located at margin of the upper Juruá River, in the State of Acre. Pedra Preta locality has yielded two specimens of the rodent Phoberomys burmeisteri and teeth of the toxodontidae Gyrinodon. The black coloration of the cervical vertebra of Stupendemys souzai sp. nov. coming from Pedra Preta is very possibly derived from the black coated conglomerate referred by Paula Couto (1978) and Simpson \& Paula Couto (1981). Campbell et al. $(2000,2001)$ suggested that all the fossils from Pedra Preta are late Miocene in age.

Bandeira. This locality (=cachoeira do Bandeira, Rio Acre) is situated in Acre River at Brazil and Bolivia border (Radambrasil, 1976; Kay \& Frailey, 1993). The outcrop consists of consolidated, ferruginous cemented sandstones in the bottom and sides of the river channel (Gaffney et al., 1998). The vertebrate fauna, mostly aquatic is especially rich with very well preserved specimens: Osteichthyes (Acregoliath rancii, Colossoma macropomum, Paleohoplias assisbrasiliensis, Phractocephalus sp.), Dipnoi (Lepidosiren paradoxa), Alligatoridae, Nettosuchidae, Crocodylidae, Gavialidae; turtles (Chelus colombiana, and Stupendemys souzai sp. nov.), and birds, with Anhing a fraileyi. The mammal fauna includes primates (Stirtonia), xenarthran sloths, toxodontids, rodents and river dolphins (Bocquentin \& Guilherme, 1997; Gaffney et al., 1998; Gayet et al., 2003).

In the last 20 years, extensive geological studies have shown that the Formation Solimões was mainly formed in a fluviolacustrine system originated during the Middle Miocene as a result of the uplift of the Eastern Cordillera during the late Miocene to Pliocene (Räsänen et al., 1995; Lundberg et al., 1998). Subsequently, northwestern Amazonia was at least partially uplifted and the marine connection with the north was closed (Hoorn, 1993, 1996). The Rio Acre local fauna (Frailey, 1986, Kay \& Frailey, 1993; Czaplewski, 1996), exposed along the banks and floodplain of the Acre River basin, is assigned to the Huayquerian and Montehermosan land-mammal ages (Late Miocene-Pliocene; Latrubesse et al.,1997; Bergqvist et al., 1998). In accordance with the sedimentary model proposed by Latrubesse $e t$ al. (1997) the occurrence of medium and large vertebrates, represented by giant crocodile (Purussaurus brasiliensis) and turtles, suggest floodplain and lacustrine environmental conditions associated to rivers, grasslands and gallery forests. 


\section{MATERIALS AND METHODS}

The material described here come from the Solimões Formation outcrop (see locality descriptions above), in the Acre State (Figure 1). All material is housed in the collection of the paleontology at the Universidade Federal do Acre (UFAC), Rio Branco, Acre.Measurements of the humerus were made with a calliper. Measurements include anteroposterior diameter (AP) and dorsoventral diameter (DV).

Materials. Stupendemys souzai sp. nov.: UFAC 1764, right humerus; UFAC 1544, left pleural 2; UFAC 1547, right xiphiplastron and UFAC 1553, cervical vertebra; all specimens from Patos locality. UFAC 1163, cervical vertebra, from Pedra Preta; UFAC 1294, left peripheral 1 from Cavalcante; UFAC 1554, cervical vertebra and UFAC 4370, pelvic girdle, from Bandeira. UFAC 5275, cervical vertebra, from the Morro do Careca; UFAC 5508, anterior margin of the carapace and left hypoplastron, from BR 364 locality.

Abbreviations. AMNH, New York; DNPM, Departamento Nacional da Produção Mineral, Rio de Janeiro; LACM, Los Angeles County Museum; MCNC, Museo de Ciencias, Caracas, Venezuela; $\mathbf{M C Z}(\mathbf{P})$, Museum of Comparative Zoology, Paleontological collections; MPEG, Museu Paraense Emilio Goeldi, Bélem; UFAC, Universidade Federal do Acre, Rio Branco, Brasil.

\section{SYSTEMATICS}

\section{ORDER CHELONII Brongniart (Latreille) 1800 \\ SUBORDER PLEURODIRA Cope, 1864 \\ FAMILY PODOCNEMIDIDAE Cope, 1868 \\ SUBFAMILY PODOCNEMIDINAE Cope, 1868}

Stupendemys Wood, 1976

Type species. Stupendemys geographicus Wood, 1976. Occurrence. Late Miocene Urumaco Formation, Venezuela and Mio-Pliocene of the Solimões Formation, Acre State, Brazil.

Revised diagnosis. Gigantic turtle; carapace depressed; anterior margin of carapace thickened and upturned with a deep median noch at front; mesoplastra largely confined to bridge; very massive humerus with distal and proximal ends both markedly expanded; in cross-section the shaft of the humerus is triangular; cervical vertebrae with massive centra and central articular surfaces not extended out beyond the main body of the centrum.

Included species. S. geographicus, S. souzai sp. nov.

Stupendemys souzai sp. nov.

(Figures 2-4, Table 1)

Stupendemys Bocquentin \& Negri, 1993: 324

cf. Stupendemys Broin, 1993: 659

Stupendemys sp. Broin, 1993: 66

Stupendemys Bocquentin \& Guilherme, 1997: 47

Stupendemys sp. Negri \& Bocquentin, 1998: 17

Stupendemys sp. Gaffney et al., 1998
Holotype. UFAC 1764, incomplete right humerus (Figure 2), figured by Broin et al. (1993: plates 5,6,7).

Type locality. Patos (= Acre 6, LACM Locality 4611), Assisbrasil County, Acre, Brazil.

Horizon. Solimões Formation, Acre conglomerate (Frailey, 1986; Gaffney et al., 1998; Bergqvist et al., 1998).

Age. Mio-Pliocene.

Etymology. Named in honour of the palaeontologist Jonas Pereira de Souza Filho.

Diagnosis. Gigantic freshwater turtle; collar structure of the anterior margin of the carapace thick and not recurved; short and broad posterior lobe of the plastron with straight lateral sides; femoroanal sulcus of the xiphiplastron situated more anteriorly than in S. geographicus; humerus with a more slender and longer shaft than in S. geographicus; narrow centrum of the cervical vertebrae.

Paratypes. UFAC 1163, cervical vertebra; UFAC 1294, left peripheral 1;UFAC 1544, left pleural 2; UFAC 1547, right xiphiplastron; UFAC 1553, cervical vertebra; UFAC 1554 , cervical vertebra; UFAC 4370, pelvic girdle; UFAC 5275, cervical vertebra; UFAC 5508, anterior margin of the carapace and left hypoplastron; LACM 131946, nuchal bone (Gaffney et al., 1998).

Description. The incomplete right humerus UFAC 1764, type specimen of $S$. souzai sp. nov. lacks the distal extremity. The preserved part of the humerus is $26 \mathrm{~cm}$ long, the estimated total length being at least $31 \mathrm{~cm}$. The lateral (radial) process is a little incomplete near the humeral head. The large caput humerus, oval to nearly quadrangular, is preserved in nearly perfect condition The caput is located at the end of a very short neck that extends from the shaft of the humerus of about $90^{\circ}$; The main axis of the articular surface of the caput lies at a slight angle to the main axis of the shaft. The medial (ulnar) process is as larger than the lateral process. The medial process extends posteriorly from the shaft at an angle of about $45^{\circ}$. The intertubercular fossa or bicipital fossa is welldeveloped. The lateral process diverges anteriorly from the shaft at an angle of about $35^{\circ}$ It does not extends medially to the level of the medial process. At the base of the lateral process, the insertion of the latissimus dorsi muscle is clearly marked in two weak points. The ventral face of the shaft is elevated medially, the preserved distal cross-section being triangular. The shaft expands gradually toward the missing distal extremity. As a whole the element is more slender than that of S. geographicus. Wood (1976) identified the humerus

Table 1. Measurements $(\mathrm{mm})$ of the humerus in Stupendemys souzai sp. nov. (holotype, UFAC 1764) and in Stupendemys geographicus (MCZ P4378).

\begin{tabular}{l|cc} 
& UFAC & MCZ \\
& $\mathbf{1 7 6 4}$ & $\mathbf{P 4 3 7 8}$ \\
\hline length (as preserved) & 260 & 310 \\
estimated total lenght & 310 & 340 \\
maximum width of proximal expansion & 188 & 180 \\
maximum width of distal expansion & - & 150 \\
dorsoventral width at middle of shaft & 57 & 83 \\
anteroposterior width at middle of shaft & 49 & 64 \\
\hline
\end{tabular}



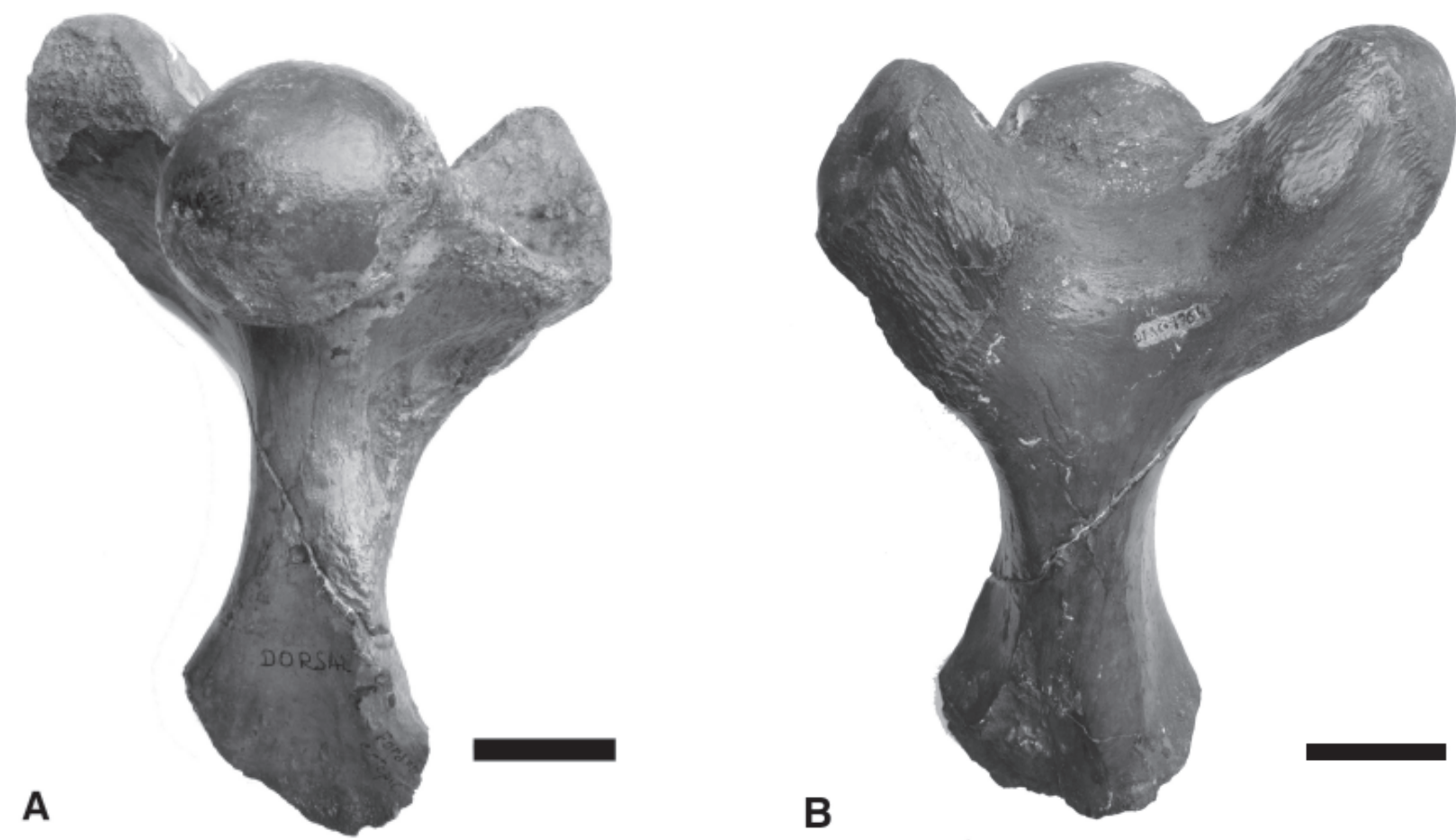

Figure 2. Stupendemys souzai sp. nov., UFAC 1764, holotype, right humerus in dorsal $(\mathbf{A})$ and ventral $(\mathbf{B})$ views. Scale bar $=5 \mathrm{~cm}$.

of S. geographicus MCZ P4378, as a left limb by comparaison with a humerus of Podocnemis expansa MCZ H4469; nonetheless, the figures show that they are both right humerus (Broin et al., 1993).

The anterior margin of the carapace UFAC 5508 from the BR 364 locality, lacks the most lateral portion of the left peripheral 1 and the posterior portion of the nuchal, the right peripheral 1 is well preserved. The round prominent border represents the collar like structure of Stupendemys Wood. In the Acre specimens UFAC 1294 and UFAC 5508 the curvature of the thick collar is developed to about the same extent seen in S. geographicus but it does not recurve. The specimen LACM 131946 from Acre 1, described by Gaffney et al. (1998), has the same morphology and it does not recurve. There is a strong median indentation at the large flange or collar at right angle to the main plate of the nuchal.

Associated with the anterior margin of the carapace and certainly from the same individual the left hypoplastron UFAC 5508 is badly crushed. Its relatively thin and nearly flat, partially covered by plastral elements. The specimen is missing some of the anterior edges at the midline and sutures with the hioplastron, the mesoplastron and the xiphiplastron are only visible for short segments. The lateral side of this hypoplastron is straight rather than curved. The width to the midline at the inguinal notch is about $30 \mathrm{~cm}$. Based upon the relative proportions of the xiphiplastron UFAC 1547 from the Patos locality, Negri \& Bocquentin (1998) suggested that the posterior lobe of Stupendemys was short and broad.

The cervical vertebra UFAC 5275 (Figure 5) from the new locality Morro do Careca has been eroded prior to discovery. Saddle shape articulation is visible anteriorly. The posterior saddle joint and the bottom of the centra are too badlly damaged to determine the original shape. Transverse processes located midway along the base of the neural arch are broken off. The left prezygapophysis is absent. The neural spine is elongate widening in an anteroposterior direction. In an anterior view the spine is fine anteriorly and thick posteriorly. The neural canal is small. The central articular facets are closed to the main body of the centrum. This cervical vertebra of S. souzai sp. nov. is similar to the probably eighth vertebra UFAC 1163 from Pedra Preta locality described by Negri \& Bocquentin (1998). These vertebrae have a prominent and high median neural spine extending along the posterior half of the neural arch. The spine makes an angle of $50^{\circ}$ with the anteroposterior axis of the centrum. Articular facets (poorly preserved) of postzygapophyses are forming an acute angle of less of ninety degrees with respect to each other. The centrum of vertebrae UFAC 5275 and 1163 are narrow and excavate laterally while in $S$. geographicus the centra are more massive. As noted by Gaffney et al. (1998), in most podocnemidids the .central articular surfaces extend out beyond the main body of the centrum. In UFAC 5275 and 1163, as in Stupendemys the central articular surfaces are close to the main body.

\section{DISCUSSION AND CONCLUSIONS}

It is well known that very large specimens of podocnemidids were present in the late Tertiary of the Amazon Basin (Rancy \& Bocquentin, 1987; Broin et al., 1993; Gaffney et al., 1998). The UFAC 1764 humerus of Acre differs from those of Podocnemis in its massiveness due to the great with of proximal and distal extremities and because its elevated shaft is less circular in cross section. Stupendemys sp. nov. 


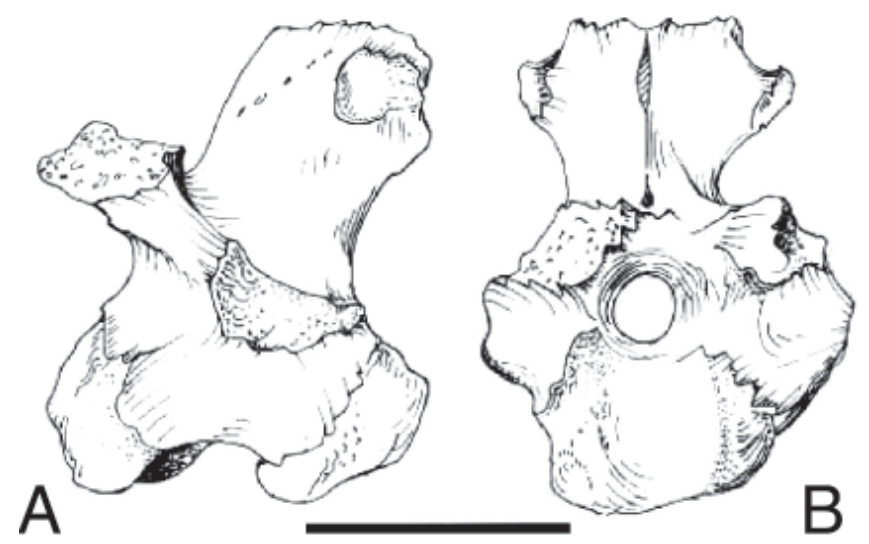

Figure 3. Stupendemys souzai sp. nov., UFAC 5275, the eighth cervical vertebra in left lateral view (A) and posterior view (B). Scale bar $=5 \mathrm{~cm}$.

shares with Stupendemys the collar-structure of the carapace and the median depression, which is absent in other podocnemidid forms (Broin et al., 1993). The probable eight cervical vertebra UFAC 5275 has neural spine that is even more prominent than that of the eighth cervical in living podocnemidids, morever the central articular surfaces are close to the main body of the centrum..

Stupendemys souzai sp. nov. differs from S. geographicus by the following combination of characters: the humerus has a more slender shaft than in S. geographicus; the femoroanal sulcus of the xiphiplastron of S. souzai is located more anteriorly than in the venezuelan species and the centra of the cervical vertebrae are narrower and more excavated laterally. The rich local Acre fauna is not strictly comparable to the Late Miocene Urumaco local fauna. The vertebrate fauna of Urumaco includes terrestrial, freshwater and littoral turtles. The paleoenvironments were tropical near shore marine to low costal savannas with freshwater rivers (Aguilera, 2004; Diaz de Gamero \& Linares, 1989). Stupendemys geographicus was evidently a highly aquatic and gigantic form; the size of the shell of a specimen exposed at the MCNC (Venezuela ) is $318 \mathrm{~cm}$. According to Wood (1976), the type of S. geographicus was found west of the Quebrada Tio Gregorio and the horizon is the "capa de tortugas" known presently by the occurrence of the littoral Bairdemys turtle. Stupendemys geographicus, probably, inhabited the littoral too. The Acre fauna is continental. The marine influence should be only marginal and not so extreme as Räsänen (1995) suggested.

No functional or adaptative explanation for the development of such a large collar-structure of Stupendemys is immediately obvious. The morphological diversity in the curved margin at right angles to the nuchal among the two species of Stupendemys was probably reflect in a diversity of swimming strategies. The thick vertical structure of the collar at front of the flattened shell suggests that $S$. souzai sp. nov. was not a good swimmer against swift currents. $S$. souzai sp. nov. appears to have retreated into swamps and

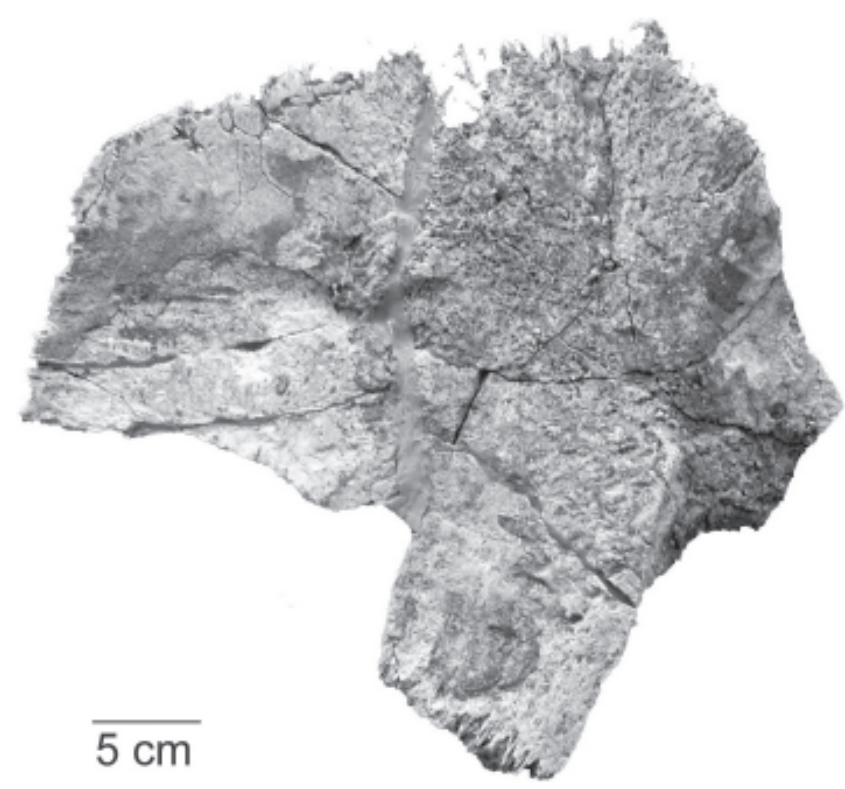

Figure 4. Stupendemys souzai sp. nov., UFAC 5508, left hypoplastron in ventral view. Scale bar $=5 \mathrm{~cm}$.

small streams for survival. The feeding habits of the species are not known but the appearance suggests a predaceous bottom-dweller. According to Alvarenga et al. (2003) the various vertebrate recorded from the Solimões Formation "indicate an expansive flooded region during the late Miocene early Pliocene, with large bodies of fresh water, and surrounded by open vegetation intersperced with forests."

\section{ACKNOWLEDGEMENTS}

The authors are grateful to Edson Guilherme (UFAC) for his interesting comments and suggestions on the manuscript and Orangel Aguilera (Universidad Nacional Experimental Francisco de Miranda, Coro, Venezuela) for a constructive review. Alceu Ranzi and Francisco Ricardo Negri provided information and access to the specimens.

\section{REFERENCES}

Aguilera, O. 2004. Tesoros paleontológicos de Venezuela: Urumaco, Patrimonio Natural de la Humanidad. Editorial Arte, 148p.

Alvarenga, H.M.F. \& Guilherme, E. 2003. The anhingas (Aves: Anhingidae) from the upper Tertiary (Miocene-Pliocene) of southwestern Amazonia. Journal of Vertebrate Paleontology, 23(3):614-621.

Baya, E.M. \& Bocquentin, J. 1997. Uma mandibula de Trigodon sp. nov. (Mammalia, Notoungulata, Toxodontidae) no Neógeno do alto rio Acre, Estado do Acre, fronteira Brasi-Peru. Geociências, 2(6):39-43.

Bergqvist, L.P.; Ribeiro, A.M. \& Bocquentin-Villanueva, J. 1998. Primata, Roedores e Litopternas do Mio/Plioceno da Amazônia Sul-Ocidental (Formação Solimões, Bacia do Acre), Brasil. Geologia Colombiana, 23:19-29.

Bocquentin, J. \& Guilherme, E. 1997. A cintura pélvica do quelônio Stupendemys (Podocnemididae, Podocnemidinae) proveniente 
do Mioceno superior-Plioceno do Estado do Acre, Brasil. Acta Geologica Leopoldensia, 20(45):47-50.

Bocquentin, J. \& Negri, F.R. 1993. Sobre la ocorrência do quelônio gigante Stupendemys (Pleurodira; Podocnemididae, Podocnemidinae) no Mioceno-superior Plioceno da Amazônia sul-ocidental. Ameghiniana, 30(3):324-325.

Broin, F.; Bocquentin, J. \& Negri, F.R. 1993. Gigantic Turtles (Pleurodira, Podocnemididae) from the late Miocene-early Pliocene of South Western Amazon. Bulletin de l'Institut français d'études andines, 22(3):657-670.

Campbell Jr., K.E. 1996. A new species of Giant Anhinga (Aves: Pelecaniformes: Anhingidae) from the Miocene (Huayquerian) of Amazonian Peru. Contributions in Science, Los Angeles County Museum, 460:1-9.

Campbell Jr., K.E.; Frailey, C. \& Pittmann, L.R. 2000. The late Miocene Gomphothere Amahuacatherium peruvium (Proboscidea, Gomphotheriidae) from Amazonian Peru. Instituto Geologico, Minero y Metalurgico, Serie Estudos Regionales, 152 p. (Boletin 23)

Campbell Jr., K.E.; Heizler, M.; Frailey, C.D.; Romero-Pittman, L. \& Prothero, D.R. 2001. Upper Cenozoic chronostratigraphy of the southwestern Amazon. Geology, 29(7):595-598.

Carvalho, P.; Bocquentin, J. \& Lapparent de Broin, F. 2002. Une nouvelle espèce de Podocnemis (Pleurodira, Podocnemididae) provenant du Néogène de la formação Solimões, Acre, Brésil. Geobios, 35:677-686.

Czaplewski, N.J. 1996. Opossums (Didelphidae) and Bats (Noctilionidae and Molossidae)from the Late Miocene of the Amazon Basin. Journal of Mammalogy, 77(1):84-94.

Diaz de Gamero, M.L. \& Linares. O 1989. Estratigrafia y Paleontologia de la Formación Urumaco, del Mioceno Tardío de Falcón Norroccidental. In: CONGRESO GEOLOGICO VENEZOLANO, 7. Memorias, 1:419-438.

Frailey, C.D. 1986. Late Miocene and Holocene Mammals, exclusive of the Notoungulata, of the Acre region, western Amazonia. Contributions in Science, Los Angeles County Museum, 374:1-43.

Gaffney, E.S.; Campbell, K.E. \& Wood, R.C. 1998. Pelomedusoid side-necked turtles from late Miocene sediments in southwestern Amazonia. American Museum Novitates, 3245(5):1-11.

Gayet, M.; Jegu, M.; Bocquentin, J. \& Negri, F.R. 2003. New characoids from the Cretaceous and Paleocene of Bolivia and the Mio-Pliocene of Brazil: phylogenetic position and paleobiogeographic implications. Journal of Vertebrate Paleontology, 23(1):28-46.
Hoorn, C. 1993. Marine incursions and the influence of Andean tectonics on the Miocene depositional history of northwestern Amazonia: Results of a palynostatigraphic study. Palaeogeography, Palaeoclimatology, Palaeoecology, 105:267-309.

Hoorn, C. 1996. Miocene Deposits in the Amazonian Foreland Basin. Science, 273:122.

Kay, R.F. \& Frailey, C.D. 1993. Large fossil platyrrhines from the Rio Acre local fauna, late Miocene, western Amazonia. Journal of Human Evolution, 25:319-327.

Latrubesse, E.M.; Bocquentin, J.; Santos, J.C. \& Ramonell, C.G. 1997. Paleoenvironmental model for the Late Cenozoic of southwestern Amazonia: Paleontology and Geology. Acta Amazonica, 27(2):103-118.

Lundberg, J.G.; Marshall, L.G.; Guerrero, J.; Horton, B.; Malabarba, M.C. \& Wesselingh, F. 1998. The stage for neotropical fish diversification: A history of tropical South American rivers. In:: L.R. Malabarba; R.E. Reis; R.P. Vari; Z.M. Lucena \& C.A.S. Lucena (eds.) Phylogeny and Classification of Neotropical Fishes, Edipucrs, p. 13-48.

Negri, F.R. \& Bocquentin, J. 1998. Vértebras cervicais e xifiplastrão de Stupendemys sp. (Chelonii, Podocnemididae, Podocnemidinae) no Mio-Plioceno do Estado do Acre e da região frontereiriça Brasil-Peru. Boletim do Museu Paraense Emilio Goeldi, 10:17-27.

Paula Couto, C. de 1978. Fossil mammals from the Acre, Brazil 2Rodentia Caviomorpha, Dinomyidae. Iheringia, Sér. Geol .5:3-17

Radambrasil. 1976. Levantamento de recursos naturais (Geologia, geomorfologia, pedologia, vegetação, uso potencial da terra) Folha SC,19 Rio Branco. 12. Departamento Nacional de Produção Mineral, Rio de Janeiro, 464 p.

Rancy, A. \& Bocquentin, J. 1987. Dois Quelônios do Neógeno do Acre, Brasil. In: CONGRESSO BRASILEIRO DE PALEONTOLOGIA, 10, 1987. Anais, Rio de Janeiro, p.181187.

Räsänen, M.; Linna, A.; Santos, J. \& Negri, F. 1995. Late Miocene tidal deposits in the Amazonian foreland basin. Science, 269:386-390.

Simpson,G. G. \& Paula Couto, C. de. 1981. Fossil mammals from the Cenozoic of Acre, Brazil III.- Pleistocene Edentata Pilosa, Proboscidea, Sirenia,Perissodactyla and Artiodactyla. Porto Alegre, Iheringia,Sér. Geol., 6:11-73.

Wood, R.C. 1976. Stupendemys geographicus, the world's largest turtle. Breviora, 436:1-29.

Received in April 2005; accepted in December, 2005. 